ELORE (ISSN 1456-3010), vol. 20 - 1/2013.

Julkaisija: Suomen Kansantietouden Tutkijain Seura ry.

[http://www.elore.fi/arkisto/1_13/mahlamaki.pdf]

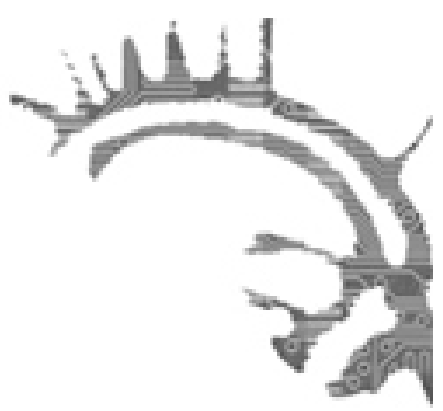

KirJa-ARViO

\title{
TARINA JA SEN TULKINTAA
}

HURTIG, JOHANNA \& LEPPÄNEN, MARI (toim.) 2012: Maijan tarina. Lapsen seksuaalinen hyväksikäyttö yksilön ja yhteisön traumana. Helsinki: Kirjapaja. 168 sivua.

Tiina Mahlamäki

Vuoden 2010 syksyllä julkisuudessa keskusteltiin vanhoillislestadiolaisen liikkeen sisällä tapahtuneista lasten seksuaalisista hyväksikäyttötapauksista. Pohdittiin, mikä nimenomaan tässä yhteisössä - tai ylipäätään uskonnollisessa yhteisössä - on sellaista, että se sallii ja mahdollistaa laajamittaiset ja pitkään jatkuneet insesti- ja pedofiliatapaukset. Erityisen vaikeaa liikkeen ulkopuolisten oli ymmärtää sitä, että lasten hyväksikäytöstä kiinnijääneet voivat anteeksipyytämällä ja -saamalla jatkaa toimintaansa ja säilyttää arvostetun asemansa liikkeen sisällä.

Johanna Hurtigin ja Mari Leppäsen toimittamassa teoksessa Maijan tarina. Lapsen seksuaalinen hyväksikäyttö yksilön ja yhteisön traumana saa äänen uhri, Maijaksi nimetty. Hän kertoo oman tarinansa, joka on täynnä hylkäämistä, hyväksikäyttöä ja väkivaltaa. Maijan narratiivin jälkeen teoksessa on neljä asiantuntijapuheenvuoroa, jotka eri näkökulmista tarkastelevat kertomusta. Vanhoillislestadiolaisuus on myös useiden teoksen toimittajien uskonnollinen koti, joskin heidän suhteensa liikkeeseen on ongelmallinen. Hurtig on tutkija, joka on keskustellut paljon julkisuudessa lasten hyväksikäytöstä, ja joka irtautui liikkeestä ja sen arvomaailmasta. Liike itse taas teki pesäeroa teologi Mari Leppäseen siinä vaiheessa kun hänet vihittiin papiksi. Naispappeutta ei liikkeessä hyväksytä. 
Tässä teoksessa ei kuitenkaan rakenneta vanhoillislestadiolaisesta liikkeestä kuvaa läpikotaisin mädäntyneenä yhteisönä. Liike tarjoaa hengellisen kodin kymmenille tuhansille suomalaisille huolimatta julkisuuteen tulleista väärinkäytöksistä ja ongelmista. Teoksen sanoma on pikemminkin sama, jota Aini Linjakumpu hoitokokouksia käsittelevässä tutkimuksessaan Haavoitettu yhteisö tuo esiin: liikkeen opillinen rakenne tarjoaa mahdollisuuden niin hyvään kuin pahaan.

\section{UHRIKERTOMUS}

Maijan tarina ei ole haastattelulitteraatio, vaan toimittajan rakentama yhtenäinen ja yksiääninen kertomus, uhrinarratiivi. Muille kuin Maijan näkökulmille ei anneta tilaa. Hänen läheistensä kertomus tapahtuneesta olisi toisenlainen. Maijan kertomusta voidaan pitää myös häntä voimaannuttavana, sillä vasta kertomusta rakentaessaan Maija saa oman äänensä kuuluviin, oman kokemuksensa sanoitettua. Maijan kertomuksen punaisena lankana onkin ajatus siitä, miten hänen ajatuksensa, näkökulmansa ja kokemuksensa on sekä hänen lapsuuden perheessään että yhteisössään kerta toisensa jälkeen sivuutettu ja mitätöity.

Maija on kokenut lapsuudessaan rakkaudettomuutta, mutta myös suoranaista seksuaalista väkivaltaa ja hyväksikäyttöä. Hyväksikäyttö jatkui vuosikausia, ja siihen liittyi myös yhteisöstä ulossulkemista sekä syyllistämistä. Maijan kokemuksia ei kuitenkaan uskottu, ja ne painuivat myös hänen oman muistinsa ulottumattomiin. Teini-iässä hän pakeni pahaa oloa päihteisiin, ei kyennyt suojaamaan rajojaan ja joutui kerran toisensa jälkeen miesten hyväksikäyttämäksi. Avioiduttuaan ja saatuaan lapsia muistot lapsuuden seksuaalisesta väkivallasta nousivat pintaan, mutta hänen edellytettiin vaikenevan kokemuksistaan. Hyväksikäyttäjät olivat pyytäneet anteeksi tekojaan ja yhteisön annettua ne anteeksi, niistä ei saanut enää puhua eikä viedä maallisen oikeuden eteen. Vain yksi hyväksikäyttäjä katui aidosti tekoaan, ja hänelle Maija myös antoi anteeksi. Traumaattiset kokemukset olivat monin tavoin vaikuttaneet Maijan ruumiiseen, joka oirehti ja lukkiutui erityisesti seksuaalisuuden edessä, mutta myös joutuessaan kohtaamaan hyväksikäyttäjiään.

Lapset ovat Herran lahja, eikä vanhoillislestadiolaisessa liikkeessä suvaita ehkäisykeinoja. Tämän vuoksi liike tunnetaankin suurperheistään. Mutta se tunnetaan myös ennen aikojaan väsyneistä ja vanhentuneista naisista, jotka uupuvat suuren lapsijoukkonsa keskelle, ja joiden terveys ei kestä jatkuvasti toistuvia raskauksia. Yhteisön mukaan ketään ei pakoteta riskeeraamaan henkeään ja terveyttään, mutta käytännössä näin tapahtuu, sillä abortti tai sterilisaatio nähdään uskon kysymyksinä. Valitsemalla abortin tai sterilisaation, nainen voi pelastaa henkensä, mutta menettää samalla taivaspaikkansa. Onko valinta siis vapaaehtoinen? Maijankin toistuvat raskaudet vahingoittivat hänen elimistöään, mutta läkärin ehdottamaa sterilisaatiota hän ei voinut ottaa, sillä uskovan ihmisen ei tullut edes ajatella sellaista. Jos Maija kuolisi raskauteensa, se olisi Herran tahto. Viimeisestä raskaudesta oli vähällä tulla kohtalokas, mutta Maija ja lapsi selvisivät hengissä. Revennyt ja hapero kohtu jouduttiin poistamaan, joten hänen ei tarvinnut lopultakaan tehdä päätöstä itse. 
Maija pyrki monin tavoin hakemaan apua. Hän kokeili erilaisia terapiamuotoja, mutta ensisijaisesti pyrki tukeutumaan perheeseensä ja uskonnolliseen yhteisöönsä. Perheen ja yhteisön näkökulmasta Maijan totuudenetsintä nähtiin kaikkia osapuolia vahingoittavana ja liian raskaana, joten hänet yritettiin vaientaa. Kertomus päättyy kuitenkin valoisasti, sillä Maija selviytyy lääketieteen, puolisonsa sekä uskonnon tuella.

\section{SELVIYTYMISNARRATIIVI}

Psykoterapeutti Eero Salin tarkastelee Maijan kertomusta trauman syntynä ja siitä selviytymisenä: hän näkee Maijan tarinan myös selviytymiskertomuksena. Traumaattiset kokemukset koteloituvat mielen syvyyksiin, mutta tihkuvat esiin vaikkapa ruumiillisina oireina, takaumina, elimistön kramppitiloina ja toimimattomuuksina, lukkiutumina, mutta myös masennuksena, ahdistuksena ja itsetuhoisena käyttäytymisenä. Terapian lisäksi traumasta voi selviytyä läheisten tuella sekä löytämällä voimaa elämän hyvistä hetkistä. Keskeistä on löytää tieto oman elämän merkityksestä ja tärkeydestä, esimerkiksi Maija tietää olevansa korvaamaton omien lastensa äitinä. Maijan tapauksessa myös uskosta kiinnipitäminen on voimauttava teko. Hän ei luovu uskostaan eikä kyseenalaista uskoaan, vaikka uskonveljet ja -sisaret usein kohtelevat väärin.

Johanna Hurtig on kuunnellut ja lukenut useita vastaavanlaisia kertomuksia ja pystyy tarkastelemaan Maijan tarinaa suhteessa niihin. Hän näkee seksuaalisen hyväksikäytön sekä siitä vaikenemisen seurakuntaruumiin sairautena, eräänlaisena autoimmuniteettisairautena, jolloin yhteisön toiminta kääntyy sitä itseään vastaan: "Ydintoiminto, kuten ajatus syntien anteeksiantamuksesta, vinoutuu väkivallan välineeksi, lähimmäisenrakkaus kuihtuu ja unohtuu. Totuudesta tulee kauppatavaraa tai sopimuksenvaraisen neuvottelun kohde" (s. 143). Koska kirjoittajan oma uskonnollinen tausta on liikkeessä, hän tunnistaa myös sen tarjoaman yhteisöllisen ja henkisen tukevan voiman - josta myös Maija kokemuksistaan huolimatta ammentaa. Mutta Hurtig uskaltaa myös esittää vaatimuksia liikkeen johdolle, samoin teki Aini Linjakumpu oman tutkimuksensa päätteeksi.

Teologi Heikki Nenosen ääni on sekin liikkeen sisältä nouseva ääni, joka kutsuu yhteisöään keskusteluun, vuoropuheluun ja avautumiseen. Hän tarkastelee puheenvuorossaan Maijan tarinan esiin nostamia moraalisia ja eettisiä kysymyksiä, jotka liikkeen sisällä muuttuvatkin uskon kysymyksiksi. Sterilisaation tai ehkäisyn pohdinta nähdään uskosta luopumisena tai rikosoikeuden ratkaistaviksi kuuluvat teot sovitaankin liikkeen sisällä, "niin kuin uskovaiset tekevät". Nenosen mukaan vanhoillislestadiolaisuudessa etiikka korvautuu "uskonelämän" käsitteellä, jolloin Maijan kokema väkivalta nähtiin syntinä, josta voi puhdistua anteeksiannon avulla.

Teoksen viimeinen teksti on tutkija Merja Laitisen viisas puheenvuoro, jossa Maijan tarinaa tulkitaan hiljaisuuden, puheen, tiedon ja tietämättömyyden ulottuvuuksilla. Seksuaalisen hyväksikäytön uhri tarvitsee tietoista kuuntelijaa, kuulluksi tulemista ja mahdollisuutta sanoittaa omat kokemuksensa. Nyt julkaistu Maijan tarina on hänen mahdollisuutensa purkaa anonyymisti puhumattomuuden kehä ja jakaa kokemuksensa ilman, että joutuu syyllistämään tai syyttämään ketään tiettyjä henkilöitä. Maija haluaa 
"vaikuttaa, muuttaa ja parantaa asioita uhrin näkökulmasta katsottuna" (s. 165). Maijan puheenvuoro on poliittinen ja emansipatorinen teko.

\section{Ahdistava vai voimauttava lukukokemus?}

Maijan tarina valittiin vuoden 2012 kristilliseksi teokseksi. Se on siis tärkeä kirja. Vaikka kärsimysten lukeminen on ahdistavaa, se on varmasti myös voimauttava henkilöille, joilla on samankaltaisia kokemuksia vaikkapa hyväksikäytöstä, hylkäämisestä, väkivallasta, insestistä tai hengellisestä väkivallasta. Teos nostaa esiin tärkeitä keskustelunaiheita, ravistelee ja ravisuttaa. Tarinaa seuraavat asiantuntijapuheenvuorot avaavat hyvällä tavalla tarinaa eri näkökulmista tarjoten välineitä myös muunlaisten tarinoiden tarkasteluun. Tämäntyyppisen, hyvin arkaluontoisia ulottuvuuksia sisältävän elämäntarinan voisi rakentaa myös yhdistämällä usean eri henkilön kokemuksia ja elämänkulkua yhtenäiseksi tarinaksi. Näin anonymiteetin säilyminen olisi vielä turvatumpaa.

\section{KirJallisuUs}

LINJAKUMPU, AINI 2012: Haavoittunut yhteisö. Hoitokokoukset vanhoillislestadiolaisuudessa. Tampere: Vastapaino.

Kirjoittaja on dosentti ja uskontotieteen yliopisto-opettaja Turun yliopiston historian, kulttuurin ja taiteiden tutkimuksen laitoksella. 